\title{
KAJIAN TINGKAT PARTISIPASI DAN KONSUMSI IKAN DITINJAU DARI ASPEK REGIONAL KOTA DAN DESA DIINDONESIA
}

\author{
Subhechanis Saptanto, Siti Hajar Suryawati dan Sonny Koeshendrajana")
}

\begin{abstract}
ABSTRAK
Penelitian ini bertujuan untuk mengkaji tingkat partisipasi dan konsumsi ikan di masyarakat perkotaan dan pedesaan berkaitan dengan pemenuhan gizi masyarakat. Metode yang digunakan adalah metode analisis deskriptif dan studi literatur. Data yang digunakan dalam kajian ini adalah data SUSENAS tahun 1996, 1999, 2002. Hasil kajian menunjukkan bahwa tingkat partisipasi konsumsi ikan di wilayah perkotaan umumnya lebih tinggi daripada daerah pedesaan. Jenis kelompok ikan yang diawetkan lebih banyak dikonsumsi oleh masyarakat yang berada di daerah pedesaan. Terjadi perubahan pola konsumsi pangan hewani pada tahun 1999 di daerah perkotaan yakni dari daging beralih ke ikan sedangkan tahun 1996 masyarakat pedesaan lebih banyak mengkonsumsi ikan. Tingkat konsumsi untuk berbagai jenis kelompok ikan di daerah perkotaan umumnya lebih tinggi jika dibandingkan dengan daerah pedesaan kecuali untuk kelompok ikan yang diawetkan.
\end{abstract}

\section{ABSTRACT: Assessment of level participation and fish consumption from the viewed of regional aspect (Urban and Rural) in Indonesia. By: Subhechanis Saptanto, Siti Hajar Suryawati and Sonny Koeshendrajana}

The objective of this study is to analyze the level participation and consumption level of fish in society regional aspect (umban and rural). Descriptive methods and literature review were used in this study. Data used in this study was based on the SUSENAS (National Socio-Economic Survey) of BPS (Central Bureau of Statistics) in 1996, 1999 and 2002. Results showed that fish consumption participation level, generally in urban areas, was bigger than in rural areas but not for the commodity of preserved fish. Food consumption pattern in urban areas has changed in 1999 from meat to fish. Whereas for the rural areas, since 1996, generally consumed fish. For fish consumption level, it was generally bigger in urban areas, except for the commodity of preserved fish.

KEYWORDS: participation level, fish consumption, regional

\section{PENDAHULUAN}

Tiga perempat dari luas wilayah Indonesia adalah laut dengan luas $\pm 5,8$ juta $\mathrm{km} 2$ dimana 3,1 juta $\mathrm{km}^{2}$ perairan teritorial dan 2,7 juta $\mathrm{km}^{2}$ perairan zona ekonomi ekslusif (ZEE). Selain itu Indonesia memiliki 17.508 buah pulau dengan bentangan pantai terpanjang kedua di dunia yakni $81.000 \mathrm{~km}$. Dilihat dari potensi sumberdaya perikanannya, Indonesia memiliki potensi budidaya laut sekitar 46.7 juta ton, potensi perairan umum 356.000 ton, potensi budidaya tambak sekitar 1 juta ton, potensi budidaya air tawar 1 juta ton, serta potensi sumberdaya ikan diperkirakan sekitar 6.4 juta ton pertahun (Ditjen PK2P, 2004).

Namun wilayah laut yang luas dan jumlah sumberdaya perikanan yang sangat potensial tidak otomatis membuat masyarakat Indonesia mengkonsumsi ikan dalam jumlah yang cukup padahal ikan merupakan salah satu sumber protein hewani yang cukup tinggi di antara sumber protein hewani lainnya seperti daging, telur dan susu.

Perkembangan tingkat konsumsi ikan per kapita nasional pada periode 1997-2002 adalah sebesar $4.11 \%$. Pada tahun 2002, konsumsi ikan di Indonesia adalah sebesar $23.29 \mathrm{~kg} / \mathrm{kap} / \mathrm{tahun}$. Jika dibandingkan dengan beberapa negara lain yang termasuk ke dalam negara penghasil ikan dunia, maka Indonesia adalah negara dengan konsumsi ikan per kapita paling rendah. Angka ini cukup rendah bila dibandingkan dengan negara-negara lain. Untuk negara-negara di Asia Timur yakni Jepang adalah sebesar $110 \mathrm{~kg} / \mathrm{kap} / \mathrm{tahun}$ dan Korea Selatan sekitar $85 \mathrm{~kg} / \mathrm{kap} / \mathrm{tahun}$. Di Asia Tenggara seperti negara Singapura, Malaysia, Thailand dan Philipina masing-

- Peneliti pada Balai Besar Riset Sosial Ekonomi Kelautan dan Perikanan 
masing sekitar $80 \mathrm{~kg}, 45 \mathrm{~kg}, 35 \mathrm{~kg}$ dan $24 \mathrm{~kg}$. Sedangkan untuk Amerika Serikat adalah sebesar 80 $\mathrm{kg} / \mathrm{kap} / \mathrm{tahun}$.

Tinggi dan rendahnya konsumsi ikan di Indonesia dapat dilihat dari tingkat partisipasi dan konsumsi masyarakat baik itu masyarakat perkotaan maupun pedesaan. Masyarakat perkotaan dan pedesaan memiliki perbedaan besar dari sisi pendapatan dan jenis mata pencaharian. Dari jumlah pendapatan, masyarakat perkotaan cenderung memiliki pendapatan yang lebih besar bila dibandingkan dengan masyarakat pedesaan sedangkan dari sisi mata pencaharian, masyarakat perkotaan cenderung memiliki mata pencaharian yang lebih beraneka ragam dibandingkan dengan masyarakat pedesaan. Pendekatan dari sisi wilayah kota dan desa untuk analisis tingkat partisipasi dan tingkat konsumsi dinilai penting dalam rangka perumusan kebijakan dengan sasaran masyarakat secara spesifik (Ditjen Tangkap, 2003).

Penelitian ini bertujuan untuk mengkaji tingkat partisipasi dan konsumsi ikan berdasarkan perbedaan wilayah perkotaan dan pedesaan. Hasil dari kajian diharapkan dapat memberikan gambaran kondisi tingkat partisipasi dan konsumsi ikan di masyarakat perkotaan dan pedesaan, sehingga diharapkan muncul suatu kebijakan strategis untuk perkembangan atau perbaikan tingkat konsumsi ikan sesuai dengan keadaan di kedua wilayah.

Ikan merupakan salah satu sumber makanan yang penting dalam rangka pemenuhan kebutuhan karena mengandung gizi yang cukup tinggi yakni memiliki kandungan protein sekitar $20 \%$, lemak sekitar $2-24 \%$ dan juga vitamin-vitamin yang penting bagi tubuh. (Ditjen PK2P, 2004) selain itu ikan juga memberikan asam-asam lemak tak jenuh yang esensial diperlukan bagi tubuh manusia dan sebagai sumber vitamin $A$, disamping sumber-sumber vitamin lainnya dan berbagai mineral yang diperlukan bagi tubuh manusia. Ikan juga dikenal sebagai sumber asam lemak omega 3 yang bermanfaat untuk pencegahan beberapa penyakit degeneratif dan untuk tumbuh kembang otak pada bayi (Suhardjo, 1993).

\section{METODE}

\section{Kerangka Pemikiran}

Kebutuhan konsumen akan protein hewani dalam kaitannya dengan ketahanan pangan di suatu wilayah baik itu wilayah pedesaan maupun perkotaan sangat dipengaruhi oleh permintaan produk pangan hewani baik yang berasal dari ikan maupun non ikan. UndangUndang No 7 Tahun 1996 tentang pangan mengartikan ketahanan pangan sebagai: "Kondisi terpenuhinya pangan bagi setiap rumah tangga yang tercermin dari tersedianya pangan yang cukup, baik jumlah maupun mutunya, aman merata dan terjangkau". Pengertian tersebut memiliki dua aspek yakni aspek makro dan mikro. Aspek makro berarti tersedianya pangan yang cukup dan mikro yang artinya setiap rumah tangga dapat menjangkau pangan untuk menjalani hidup sehat dan aktif.

Tingkah laku konsumen dalam mengkonsumsi produk perikanan ditentukan oleh faktor karakteristik individu dan lingkungan. Karakteristik individu menyangkut faktor usia, pendidikan, dan mata pencaharian sedangkan lingkungan adalah tempat dimana ia berada yakni di daerah perkotaan dan pedesaan (urban and rura). Wilayah perkotaan dan pedesaan merupakan wilayah yang memiliki perbedaan yang signifikan dari berbagai segi, baik itu dari segi ekonomi, sosial dan budaya. Dari segi ekonomi umumnya tingkat pendapatan masyarakat perkotaan lebih tinggi dibandingkan dengan daerah pedesaan dan dari sisi sosial budaya, masyarakat kota cenderung bersifat heterogen dikarenakan berasal dari latar belakang yang berbeda seperti pendidikan, agama dan mata pencaharian.

Secara umum permasalahan konsumsi pangan di Indonesia adalah rendahnya sumbangan yang diberikan oleh ikan untuk menu makanan sehari-hari oleh karena itu perlu dilakukan hal-hal yang berkaitan dengan peningkatan konsumsi ikan sehingga dapat memenuhi taraf kecukupan pangan.

Tingkat partisipasi konsumsi ikan merupakan proporsi jumlah rumah tangga yang mengkonsumsi jenis produk perikanan terhadap total rumah tangga contoh dan dinyatakan dalam persentase. Dalam kajian ini mencakup analisis perkembangan tingkat partisipasi konsumsi ikan yang dibedakan atas ikan segar, ikan olahan, udang segar dan udang olahan. Selain tingkat partisipasi, kajian tingkat konsumsi ikan juga dilakukan untuk mengetahui seberapa besar jumlah protein yang dikonsumsi oleh masyarakat baik itu yang berada di perkotaan maupun pedesaan dalam rangka pemenuhan gizi masyarakat. Protein merupakan salah satu zat gizi yang paling penting peranannya dalam pembangunan sumberdaya manusia. Bersama-sama dengan energi, kecukupan protein dapat digunakan sebagai indikator untuk melihat kondisi gizi masyarakat dan juga keberhasilan pemerintah dalam pembangunan pangan, pertanian, kesehatan dan sosial ekonomi secara terintegrasi (Moeloek, 1999).

Untuk mengukur seberapa besar konsumen di suatu wilayah dalam mengkonsumsi ikan sebagai salah satu sumber protein hewani diperlukan kajian tingkat partisipasi dan konsumsi. Hasil kajian ini diharapkan dapat memberikan implikasi pada: 
a. Perbaikan kinerja perencanaan pengembangan pangan hewani yang mencakup akselerasi peningkatan konsumsi, peningkatan produksi dan kebijakan ekspor impor

b. Peningkatan kinerja ketahanan pangan berkelanjutan dengan empat dimensi utama yaitu ketersediaan, aksesibilitas, vulnerabilitas dan sustainabilitas pangan.

Kebijakan strategis ketahanan pangan nasional akan menjadi mantap bila didukung oleh hasil analisis tingkat konsumsi dan tingkat partisipasi konsumsi secara komprehensif. Hasil dari analisis tingkat partisipasi dan konsumsi digunakan untuk membuat perencanaan pengembangan dalam: a). Akselerasi konsumsi; b). Peningkatan produksi; c). Kebijakan ekspor impor. Perencanaan tersebut diharapkan dapat mendukung program ketahanan pangan nasional dengan terpenuhinya kondisi seperti: 1). Ketersediaan pangan; 2). Aksesibilitas; 3) Vulnerabilitas; 4) Sustainibilitas. Kebijakan strategis ketahanan pangan nasional tidak dapat otomatis dicapai namun harus didukung oleh berbagai komponen. Salah satu komponen yang berpengaruh adalah lingkungan masyarakat yang berbeda yakni masyarakat perkotaan dan pedesaan. Sehingga kiranya diperlukan kajian analisis partisipasi dan konsumsi menurut wilayah kota dan desa. Kerangka pemikiran konsumsi ikan dalam mendukung ketahanan pangan nasional dapat dilihat pada Gambar 1.

Pada Gambar 1 dapat dilihat bahwa tingkat partisipasi dan konsumsi produk perikanan menunjukkan seberapa besar kecenderungan jumlah produk perikanan yang dikonsumsi yang kemudian dapat diketahui nilai kecukupan proteinnya. Jika nilai kecukupan protein yang berasal dari ikan telah sesuai dengan standar maka dapat dikatakan bahwa ketahanan pangan dari sisi protein telah tercapai.

\section{Jenis Sumber Data}

Kegiatan penelitian ini menggunakan data sekunder Survey Sosial Ekonomi Nasional (SUSENAS) dari Badan Pusat Statistik (BPS) tahun 1996, 1999 dan 2002. Data yang digunakan adalah data konsumsi pangan hewani tahun 1996, 1999 dan 2002 dengan

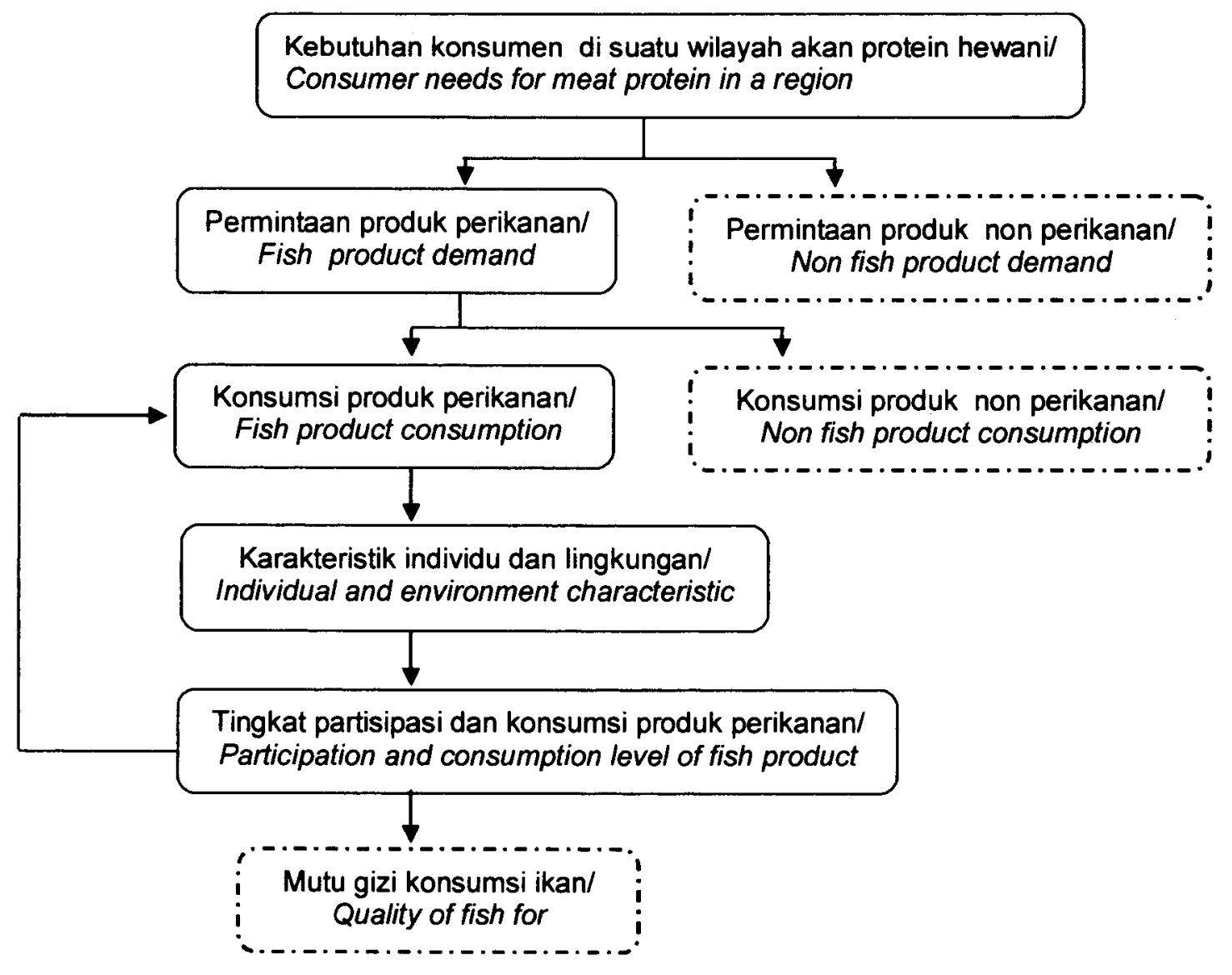

Gambar 1. Kerangka pemikiran penelitian konsumsi ikan dalam mendukung ketahanan pangan nasional. Figure 1. Framework of food consumption from meat for supporting national food security. 
pertimbangan bahwa situasi pada tahun 1996 menunjukkan kondisi sebelum krisis moneter, tahun 1999 menunjukkan kondisi krisis dan tahun 2002 menunjukkan kondisi setelah pasca krisis. Jenis-jenis ikan yang dianalisis dikelompokkan ke dalam 4 kelompok seperti yang tampak pada Tabel 1 yakni ikan segar, udang segar, ikan yang diawetkan dan udang yang diawetkan.

\section{Teknik Analisis Data}

Analisis data yang dilakukan dalam kajian ini sebagai berikut:

1. Analisis Tingkat Partisipasi Konsumsi

Tingkat partisipasi konsumsi ikan diukur dengan cara menghitung persentase responden yang mengkonsumsi per kelompok jenis ikan relatif terhadap total responden.

\section{Analisis Tingkat Konsumsi}

Tingkat konsumsi ikan dihitung berdasarkan satuan $\mathrm{kg} / \mathrm{kap} /$ tahun untuk masing-masing kelompok jenis ikan.

Cakupan dari analisis tingkat partisipasi dan tingkat konsumsi dilakukan berdasarkan pembagian wilayah yaitu untuk daerah perkotaan (urban) dan pedesaan (rura). Analisis data bersifat deskriptif kuantitatif secara tabulatif.

\section{HASIL DAN BAHASAN}

\section{Peranan Ikan Dalam Konsumsi Pangan Hewani}

Ikan termasuk salah satu jenis pangan hewani yang memiliki kandungan protein cukup besar sehingga dilakukan komparasi dengan jenis pangan

Tabel 1. Jenis ikan yang dianalisis dalam studi tingkat partisipasi dan konsumsi ikan di Indonesia, 1996-2002

Table 1. Fish species to be analyzed in study participation and fish consumption level in Indonesia, 1996-2002

\begin{tabular}{|c|c|c|}
\hline No & $\begin{array}{l}\text { Kelompok ikan/ } \\
\text { Fish group }\end{array}$ & $\begin{array}{l}\text { Jenis ikanl } \\
\text { Fish type }\end{array}$ \\
\hline 1 & $\begin{array}{l}\text { Ikan segarl } \\
\text { Fresh fish }\end{array}$ & $\begin{array}{l}\text { Ekor kuning/Yellow tail fish } \\
\text { Tongkol-tuna-cakalang/Tunas } \\
\text { Tenggiri/Narrow barred king mackere/s } \\
\text { Selar/Trevallies } \\
\text { Kembung/Mackere/s } \\
\text { Teri/Anchovies } \\
\text { Bandeng/Milkfish } \\
\text { Lele/Catfish } \\
\text { Mujair/Tilapias } \\
\text { Mas/Common carps } \\
\text { Gabus/Snakehead fish } \\
\text { Kakap/Giant seaperch } \\
\text { Baronang/Baronang }\end{array}$ \\
\hline 2 & $\begin{array}{l}\text { Udang segar/ } \\
\text { Fresh shrimp }\end{array}$ & $\begin{array}{l}\text { Udang/Common shrimp } \\
\text { Cumi-cumi/Common squids } \\
\text { Ketam-kepiting-rajungan/Common crabs }\end{array}$ \\
\hline 3 & $\begin{array}{l}\text { Ikan yang diawetkan/ } \\
\text { Preserved fish }\end{array}$ & $\begin{array}{l}\text { Ikan kaleng/Canned fish } \\
\text { Ikan olahan/Processed fish }\end{array}$ \\
\hline 4 & $\begin{array}{l}\text { Udang yang diawetkan/ } \\
\text { Preserved shrimp }\end{array}$ & Udang olahan/Processed shrimp \\
\hline
\end{tabular}


hewani lainnya seperti daging, telur dan susu untuk melihat peranan atau posisi ikan dalam konsumsi pangan hewani lainnya. Di wilayah perkotaan seperti yang ditunjukkan pada Tabel 2 menunjukkan penurunan konsumsi ikan dari tahun 1996 sebesar $20,77 \mathrm{~kg} / \mathrm{kap}$ menjadi 16,48 kg/kap pada tahun 2002 atau mengalami penurunan sekitar $21,05 \%$.

Kejadian yang sama juga terdapat pada wilayah pedesaan dimana konsumsi ikan mengalami penurunan dari yang semula sekitar $17,42 \mathrm{~kg} / \mathrm{kap}$ pada tahun 1996 menjadi 15,48 kg/kap pada tahun 2002 atau mengalami penurunan sekitar $13,25 \%$ seperti yang ditunjukkan pada Tabel 3 .

Bila dibandingkan dengan pangan hewani lainnya, konsumsi ikan lebih besar dibandingkan dengan jenis pangan hewani lainnnya namun juga mengalami penurunan yang paling signifikan dari tahun 19962002. Pada periode 1996-1999, ikan mengalami penurunan yakni pada masa krisis moneter dan mulai pulih pada periode 1999-2002. Pada masa pemulihan ini pertumbuhan konsumsi ikan di desa meningkat lebih tinggi dibandingkan dengan di kota. Hal ini menunjukkan pengaruh krisis ekonomi lebih terasa di wilayah perkotaan bila dibandingkan dengan pedesaan.

Fenomena yang menarik adalah terjadinya perubahan pola konsumsi masyarakat perkotaan pada periode 1996-2002, dari yang semula mengkonsumsidaging beralih mengkonsumsi ikan, sedangkan sejak tahun 1996, masyarakat pedesaan pada umumnya lebih banyak mengkonsumsi ikan. Hal ini sejalan dengan krisis moneter yang terjadi, menyebabkan harga daging meningkat sehingga menyebabkan masyarakat kota beralih mengkonsumsi ikan.

\section{Tingkat Partisipasi Konsumsi Ikan \\ Masyarakat Kota dan Desa (Urban and Rural)}

Partisipasi masyarakat dalam mengkonsumsi ikan di masyarakat perkotaan dan pedesaan pada umumnya tidak banyak dipengaruhi oleh krisis moneter meski umumnya terjadi penurunan dalam

Tabel 2. Tingkat konsumsi pangan hewani menurut wilayah kota, 1996-2002

Table 2. Food consumption level by urban areas, 1996-2002

\begin{tabular}{lcccc}
\hline \multirow{2}{*}{$\begin{array}{l}\text { Jenis pangan hewani/ } \\
\text { Food type }\end{array}$} & $\begin{array}{c}\text { Tingkat konsumsi (kg/kap/tahun)/ } \\
\text { Consumption level (kg/cap/year) }\end{array}$ & $\begin{array}{c}\text { Rata -rata } \\
\text { pertumbuhan/ } \\
\text { Average growth }\end{array}$ \\
\cline { 2 - 5 } (\%)
\end{tabular}

Sumber/Source: SUSENAS, BPS (Diolah/Proccesed/)

Tabel 3. Tabel tingkat konsumsi pangan hewani menurut wilayah desa, 1996-2002

Table 3. Food consumption level by rural areas, 1996-2002

\begin{tabular}{|c|c|c|c|c|}
\hline \multirow{2}{*}{$\begin{array}{c}\text { Jenis pangan hewani/ } \\
\text { Food type }\end{array}$} & \multicolumn{3}{|c|}{$\begin{array}{l}\text { Tingkat konsum si (kg/kap/tahun)/ } \\
\text { Consumption level (kg/cap/year) }\end{array}$} & \multirow{2}{*}{$\begin{array}{c}\text { Rata -rata } \\
\text { pertumbuhan } / \\
\text { A verage growth } \\
\text { (\%) }\end{array}$} \\
\hline & 1996 & 1999 & 2002 & \\
\hline Daging/Meat & 6.73 & 3.52 & 5.48 & 2.63 \\
\hline Telur/Eggs & 4.85 & 3.22 & 4.9 & 6.15 \\
\hline Susu/Milk & 1.02 & 0.75 & 1.17 & 9.94 \\
\hline Ikan/Fish & 17.42 & 14.56 & 15.48 & -13.25 \\
\hline
\end{tabular}

Sumber/Source: SUSENAS, BPS (Diolah/Proccesed/) 
mengkonsumsi berbagai kelompok ikan (ikan segar, udang segar, ikan yang diawetkan, dan udang yang diawetkan). Pada tahun 2002 terjadi peningkatan partisipasi masyarakat di kedua wilayah. Tingkat partisipasi konsumsi ikan ditunjukkan oleh Gambar 2.

Pada Gambar 3 dapat dilihat bahwa umumnya masyarakat perkotaan memiliki tingkat partisipasi konsumsi ikan yang lebih tinggi bila dibandingkan dengan masyarakat pedesaan, kecuali untuk kelompok ikan yang diawetkan (ikan kaleng dan ikan olahan). Hal ini dimungkinkan karena masyarakat pedesaan memiliki kecenderungan untuk memilih jenis ikan yang diawetkan karena memiliki harga yang lebih murah bila dibandingkan dengan jenis ikan segar. Tingkat partisipasi konsumsi ikan cukup tinggi terjadi di tahun 1996 di kedua wilayah dimana pada tahun tersebut belum terjadi krisis moneter. Namun setelah tahun 1996

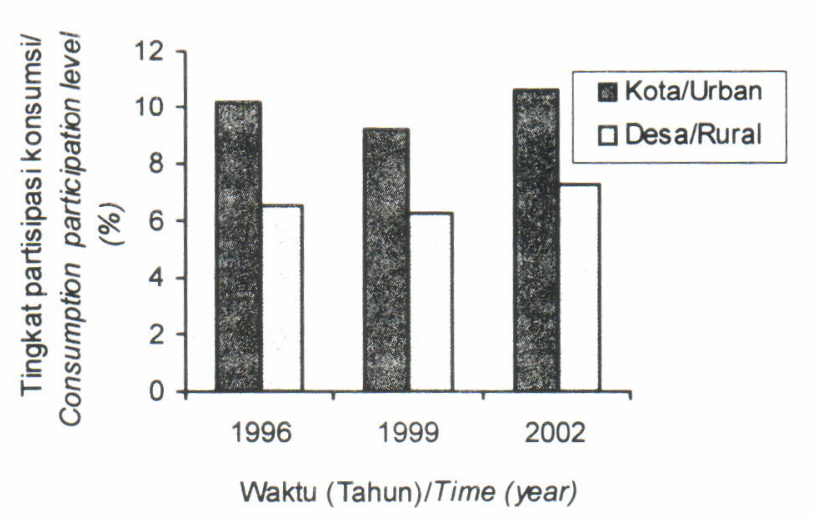

Ikan segar/Fresh fish

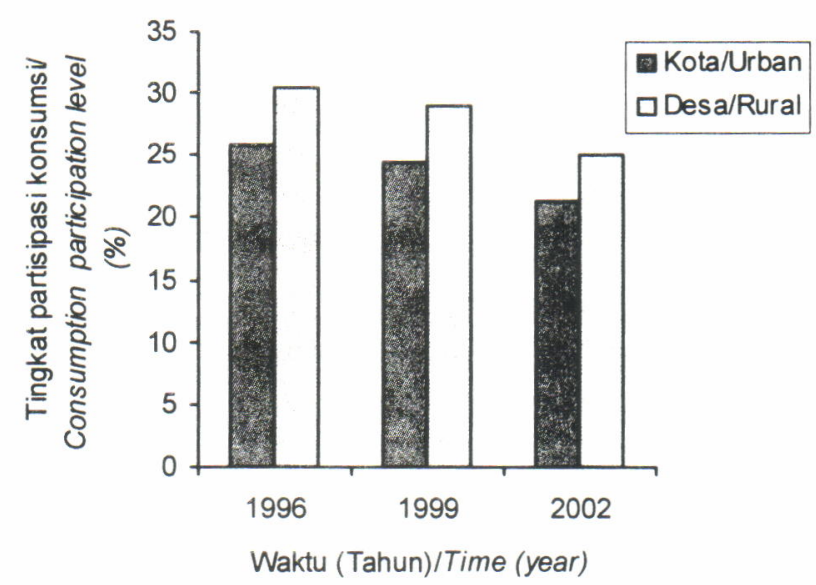

Ikan yang diawetkan/Preserved fish terjadi penurunan yang cukup signifikan di kedua wilayah yakni sebesar $5.95 \%$ dan desa sebesar $6.23 \%$. Kelompok-kelompok lain seperti pada kelompok ikan segar dan udang segar di kedua wilayah terjadi peningkatan tingkat partisipasi konsumsi ikan yang cukup signifikan pada periode 1996-1999 sedangkan untuk kelompok udang yang diawetkan di daerah pedesaan terjadi penurunan tingkat partisipasi konsumsi ikan sebesar $1.96 \%$. Dari empat kelompok ikan yang ada, masyarakat di kedua wilayah lebih banyak mengkonsumsi ikan yang diawetkan yakni di daerah perkotaan berkisar antara $21-26 \%$ dan pedesaan berkisar antara $25-30 \%$.

\section{Tingkat Konsumsi Ikan Masyarakat Kota dan Desa (Urban and Rural)}

Hasil dari pengelompokkan konsumsi untuk kelompok jenis ikan untuk wilayah perkotaan dan pedesaan dapat dilihat pada Gambar 3.

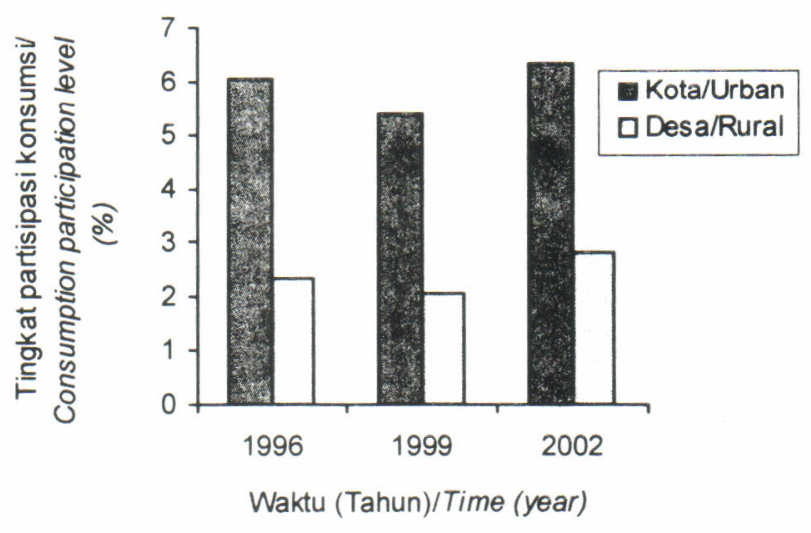

Udang segar/Fresh shrimp

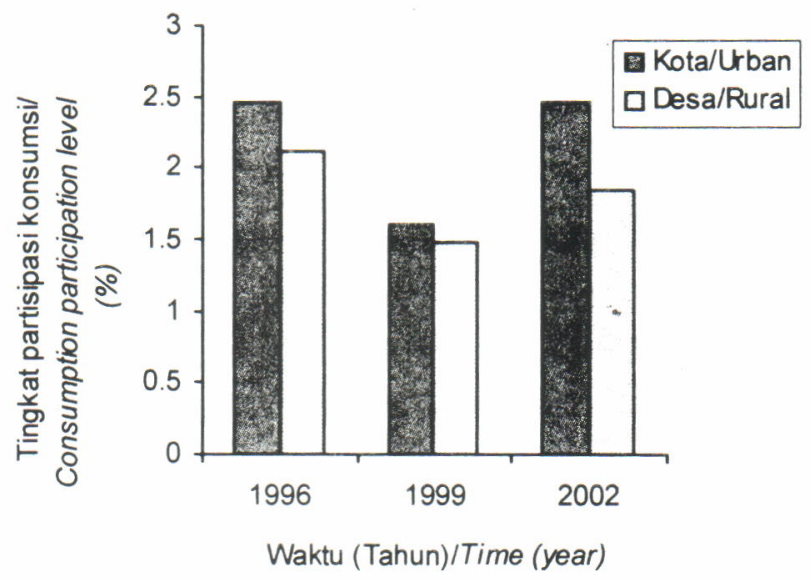

Udang yang diawetkan/Preserved shrimp

Gambar 2. Tingkat partisipasi konsumsi ikan dan udang menurut wilayah kota dan desa, 1996-2002.

Figure 2. Fish and shrimp participation level of consumption by urban and rural areas, 1996-2002. 


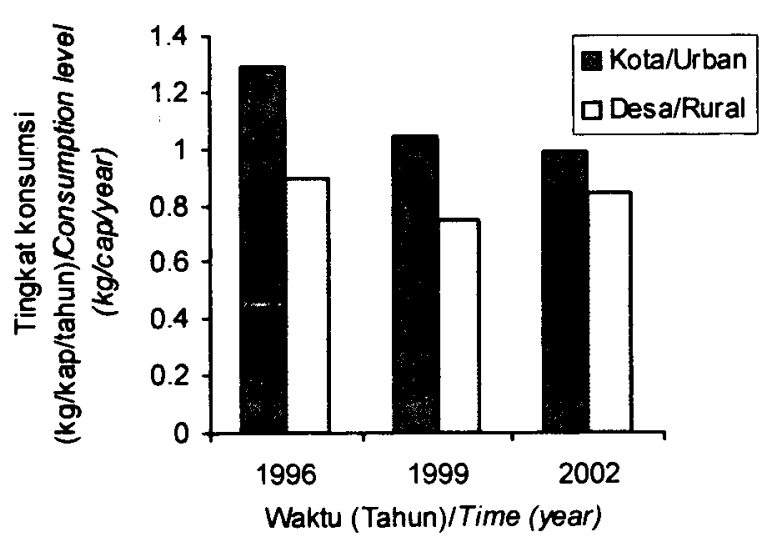

Ikan segar/Fresh fish

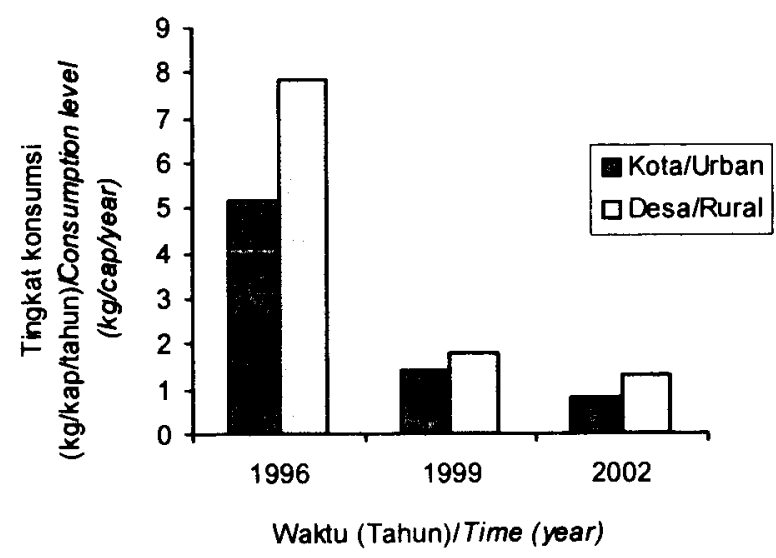

Ikan yang diawetkan/Preserved fish

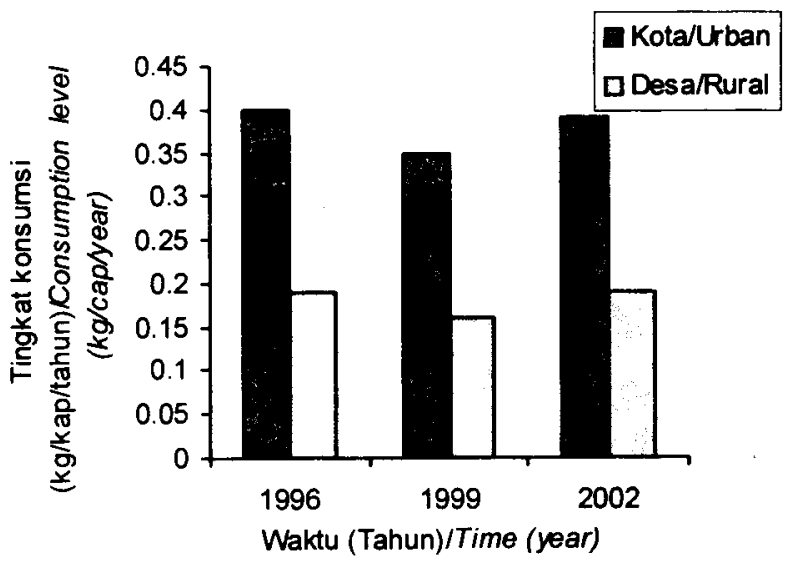

Udang segar/Fresh shrimp

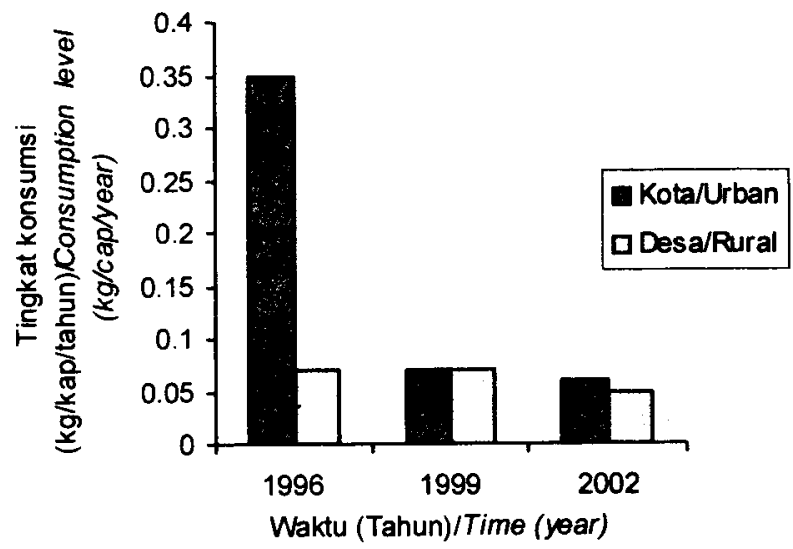

Udang yang diawetkan/Preserved shrimp

Gambar 3. Tingkat konsumsi ikan dan udang wilayah kota dan desa di Indonesia, 1996-2002.

Figure 3. Fish and shrimp level of consumption by urban and rural areas, 1996-2002.

Pada Gambar 3 dapat dilihat tingkat konsumsi ikan di daerah perkotaan umumnya lebih besar jika dibandingkan dengan daerah pedesaan, kecuali untuk kelompok ikan yang diawetkan (ikan kaleng dan olahan). Untuk kelompok ikan yang diawetkan terjadi penurunan yang cukup signifikan dalam periode tahun 1996-2002, dimana di perkotaaan sebesar $37.99 \%$ dan di pedesaan sebesar $34.78 \%$.

Terdapat kecenderungan kelompok jenis ikan olahan lebih banyak dikonsumsi oleh masyarakat pedesaan dibandingkan dengan masyarakat perkotaan selain itu diperlukan suatu kebijakan yang bertujuan untuk lebih meratakan tingkat partisipasi konsumsi dan tingkat konsumsi di kedua wilayah. Kebijakan tersebut juga hendaknya mengarah kepada peningkatan dan pemerataan pendapatan, peningkatan ketersediaan dan distribusi, serta peningkatan kesadaran pangan dan gizi sehingga dapat memperbaiki tingkat partisipasi dan tingkat konsumsi masyarakat baik di pedesaan maupun perkotaan.

\section{KESIMPULAN DAN IMPLIKASI KEBIJAKAN}

Dari hasil kajian tingkat partisipasi dan konsumsi, tidak dapat disangkal bahwa ikan memegang peranan penting dalam pemenuhan gizi masyarakat karena ikan merupakan salah satu sumber protein selain daging, telur dan susu. Hal analisis menunjukkkan bahwa tingkat pertumbuhan konsumsi ikan bila dibandingkan dengan daging, telur dan susu, ikan memiliki tingkat pertumbuhan yang paling signifikan baik di daerah kota maupun desa.

Tingkat partisipasi konsumsi ikan di wilayah perkotaan lebih besar dibandingkan dengan wilayah pedesaan namun untuk kelompok ikan yang diawetkan 
(olahan) lebih banyak dikonsumsi oleh masyarakat pedesaan. Tingkat konsumsi ikan masyarakat kota lebih tinggi dibandingkan dengan masyarakat pedesaan kecuali untuk kelompok jenis ikan yang diawetkan. Dengan adanya partisipasi konsumsi ikan olahan yang cukup tinggi di wilayah pedesaan bermakna bahwa masyarakat pedesaan tidak menghidangkan ikan segar untuk menjadi pelengkap dalam menu makanannya. Sehingga kiranya perlu dilakukan kebijakan strategis untuk perbaikan tingkat partisipasi konsumsi masyarakat pedesaan selain ikan olahan. Di lain sisi, ikan olahan bagi masyarakat perkotaan masih dianggap sebagai 'produk kelas bawah'. Hal ini merupakan tantangan bagi industri pengolahan dalam meningkatkan kualitas produknya sehingga diharapkan harganya dapat bersaing dengan ikan segar. Peningkatan kualitas produk ikan olahan dapat diikuti oleh peningkatan potensi pasar dan berdampak juga pada peningkatan kesejahteraan masyarakat nelayan. Jadi kiranya sangat perlu untuk dilakukan pengembangan sektor perikanan lebih lanjut khsusnya pada sektor industri pengolahan ikan.

Hasil kajian tingkat partisipasi dan konsumsi juga menunjukkan bahwa terdapat perbedaan antara masyarakat perkotaan dan pedesaan dalam menyikapi ikan sebagai salah satu kelompok pangan hewani termasuk ikan. Hal ini terjadi karena pada dasarnya lingkungan perkotaan dan pedesaan berbeda secara signifikan baik itu dari ekonomi dan sosial budaya. Perbedaan itu terlihat dari kelompok jenis ikan yang menjadi pilihan untuk dikonsumsi dan besarnya yang dikonsumsi sehingga kiranya perlu dimunculkan suatu rekomendasikan kebijakan yang tepat yang bertujuan untuk dapat lebih menyeimbangkan konsumsi ikan di pedesaan dan perkotaan secara proporsional.

\section{DAFTAR PUSTAKA}

Badan Pusat Statistik. 1996. Survei Sosial Ekonomi Nasional 1993. BPS, Jakarta.

Badan Pusat Statistik. 1999. Survei Sosial Ekonomi Nasional 1999. BPS, Jakarta.

Badan Pusat Statistik. 2002. Survei Sosial Ekonomi Nasional 2002. BPS, Jakarta.

Direktorat Jenderal Peningkatan Kapasitas Kelembagaan dan Pemasaran. 2004. Strategi Peningkatan Konsumsi Ikan di Indonesia. Departemen Kelautan dan Perikanan. Jakarta. 74 pp.

Direktorat Jenderal Perikanan Tangkap. 2003. Strategi Kebijakan Pemenuhan Protein Ikan Dalam Mendukung Ketahanan Pangan Nasional. Departemen Kelautan dan Perikanan. 222 pp.

Moeloek, F.A. 1999. Gizi sebagai Basis Pengembangan Sumberdaya Manusia Menuju Indonesia Sehat 2000. Dalam Pengembangan Gizi dan Pangan dari Perspektif Kemandirian Lokal. Persatuan Peminat Pangan dan Gizi dan Center for Regional Resources Development and Community Empowerment, Jakarta.

Suhardjo. 1994. Pola Konsumsi lkan di Indonesia. in Rifai, M.A. et al. Ed. Risalah Widyakarya Pangan dan Gizi V. Jakarta, 20-22 April 1993. Lembaga IImu Pengetahuan Indonesia, Jakarta. 


\section{LAMPIRAN}

Lampiran 1. Tingkat partisipasi konsumsi ikan segar menurut wilayah kota dan desa, 1996-2002

Appendix 1. Fresh fish consumption participation level by urban and rural areas, 1996-2002

\begin{tabular}{ccccc}
\hline $\begin{array}{c}\text { Wilayah/ } \\
\text { Areas }\end{array}$ & \multicolumn{3}{c}{$\begin{array}{c}\text { Tingkat partisipasi konsumsil } \\
\text { Consumption participation level (\%) }\end{array}$} & $\begin{array}{c}\text { Rata-rata pertumbuhan/ } \\
\text { Average growth (\%) }\end{array}$ \\
\cline { 2 - 4 } & $\mathbf{1 9 9 6}$ & $\mathbf{1 9 9 9}$ & $\mathbf{2 0 0 2}$ & \\
\hline Kota/Urban & 10.21 & 9.2 & 10.65 & 1.96 \\
Desa/Rural & 6.59 & 6.28 & 7.3 & 3.85 \\
\hline
\end{tabular}

Lampiran 2. Tingkat partisipasi konsumsi udang segar menurut wilayah kota dan desa, 1996-2002 Appendix 2. Fresh shrimp consumption participation level by urban and rural areas, 1996-2002

\begin{tabular}{ccccc}
\hline \multirow{2}{*}{$\begin{array}{c}\text { Wilayah/ } \\
\text { Areas }\end{array}$} & \multicolumn{2}{c}{$\begin{array}{c}\text { Tingkat partisipasi konsumsi/ } \\
\text { Consumption participation level (\%) }\end{array}$} & $\begin{array}{c}\text { Rata-rata pertumbuhan/ } \\
\text { Average growth (\%) }\end{array}$ \\
\cline { 2 - 4 } & $\mathbf{1 9 9 6}$ & $\mathbf{1 9 9 9}$ & $\mathbf{2 0 0 2}$ & \\
\hline Kota/Urban & 6.03 & 5.38 & 6.32 & 2.23 \\
Desa/Rural & 2.33 & 2.05 & 2.83 & 8.68 \\
\hline
\end{tabular}

Lampiran 3. Tingkat partisipasi konsumsi ikan yang diawetkan menurut wilayah kota dan desa, 1996-2002 Appendix 3. Preserved fish consumption participation level by urban and rural areas, 1996-2002

\begin{tabular}{ccccc}
\hline $\begin{array}{c}\text { Wilayah/ } \\
\text { Areas }\end{array}$ & \multicolumn{3}{c}{$\begin{array}{c}\text { Tingkat partisipasi konsumsi/ } \\
\text { Consumption participation level (\%) }\end{array}$} & $\begin{array}{c}\text { Rata-rata pertumbuhan/ } \\
\text { Average growth (\%) }\end{array}$ \\
\cline { 2 - 4 } & $\mathbf{1 9 9 6}$ & $\mathbf{1 9 9 9}$ & $\mathbf{2 0 0 2}$ & \\
\hline Kota/Urban & 25.79 & 24.52 & 21.35 & -5.95 \\
Desa/Rural & 30.45 & 29.03 & 24.96 & -6.23 \\
\hline
\end{tabular}

Lampiran 4. Tingkat partisipasi konsumsi udang yang diawetkan menurut wilayah kota dan desa, 1996-2002 Appendix 4. Preserved shrimp consumption participation level by urban and rural areas, 1996-2002

\begin{tabular}{ccccc}
\hline \multirow{2}{*}{$\begin{array}{c}\text { Wilayah/ } \\
\text { Areas }\end{array}$} & \multicolumn{2}{c}{$\begin{array}{c}\text { Tingkat partisipasi konsumsi/ } \\
\text { Consumption participation level (\%) }\end{array}$} & $\begin{array}{c}\text { Rata-rata pertumbuhan/ } \\
\text { Average growth (\%) }\end{array}$ \\
\cline { 2 - 4 } & $\mathbf{1 9 9 6}$ & $\mathbf{1 9 9 9}$ & $\mathbf{2 0 0 2}$ & \\
\hline Kota/Urban & 2.45 & 1.61 & 2.45 & 5.96 \\
Desa/Rural & 2.11 & 1.49 & 1.84 & -1.96 \\
\hline
\end{tabular}


Lampiran 5. Tingkat konsumsi ikan segar menurut wilayah kota dan desa, 1996-2002

Appendix 5. Fresh fish consumption level by urban and rural areas, 1996-2002

\begin{tabular}{ccccc}
\hline $\begin{array}{c}\text { Wilayah/ } \\
\text { Areas }\end{array}$ & \multicolumn{2}{c}{$\begin{array}{c}\text { Tingkat partisipasi konsumsi/ } \\
\text { Consumption participation level (\%) }\end{array}$} & $\begin{array}{c}\text { Rata-rata pertumbuhan/ } \\
\text { Average growth (\%) }\end{array}$ \\
\cline { 2 - 4 } & $\mathbf{1 9 9 6}$ & $\mathbf{1 9 9 9}$ & $\mathbf{2 0 0 2}$ & \\
\hline Kota/Urban & 1.29 & 1.04 & 0.99 & -8.06 \\
Desa/Rural & 0.9 & 0.75 & 0.84 & -1.56 \\
\hline
\end{tabular}

Lampiran 6. Tingkat konsumsi udang segar menurut wilayah kota dan desa, 1996-2002

Appendix 6. Fresh shrimp consumption level by urban and rural areas, 1996-2002

\begin{tabular}{ccccc}
\hline \multirow{2}{*}{$\begin{array}{c}\text { Wilayah/ } \\
\text { Areas }\end{array}$} & \multicolumn{2}{c}{$\begin{array}{c}\text { Tingkat partisipasi konsumsi/ } \\
\text { Consumption participation level (\%) }\end{array}$} & $\begin{array}{c}\text { Rata-rata pertumbuhan/ } \\
\text { Average growth (\%) }\end{array}$ \\
\cline { 2 - 4 } & $\mathbf{1 9 9 6}$ & $\mathbf{1 9 9 9}$ & $\mathbf{2 0 0 2}$ & \\
\hline Kota/Urban & 0.4 & 0.35 & 0.39 & -0.36 \\
Desa/Rural & 0.19 & 0.16 & 0.19 & 0.99 \\
\hline
\end{tabular}

Lampiran 7. Tingkat konsumsi ikan yang diawetkan menurut wilayah kota dan desa, 1996-2002 Appendix 7. Preserved fish consumption level by urban and rural areas, 1996-2002

\begin{tabular}{ccccc}
\hline \multirow{2}{*}{$\begin{array}{c}\text { Wilayah/ } \\
\text { Areas }\end{array}$} & \multicolumn{2}{c}{$\begin{array}{c}\text { Tingkat partisipasi konsumsi/ } \\
\text { Consumption participation level (\%) }\end{array}$} & $\begin{array}{c}\text { Rata rata pertumbuhan/ } \\
\text { Average growth (\%) }\end{array}$ \\
\cline { 2 - 4 } & 1996 & 1999 & 2002 & -37.99 \\
\hline Kota/Urban & 5.19 & 1.41 & 0.83 & -34.78 \\
DesalRural & 7.87 & 1.78 & 1.3 & \\
\hline
\end{tabular}

Lampiran 8. Tingkat konsumsi udang yang diawetkan menurut wilayah kota dan desa, 1996-2002 Appendix 8. Preserved shrimp consumption level by urban and rural areas, 1996-2002

\begin{tabular}{ccccc}
\hline \multirow{2}{*}{$\begin{array}{c}\text { Wilayah/ } \\
\text { Areas }\end{array}$} & \multicolumn{2}{c}{$\begin{array}{c}\text { Tingkat partisipasi konsumsil } \\
\text { Consumption participation level (\%) }\end{array}$} & $\begin{array}{c}\text { Rata-rata pertumbuhan/ } \\
\text { Average growth (\%) }\end{array}$ \\
\cline { 2 - 4 } & $\mathbf{1 9 9 6}$ & $\mathbf{1 9 9 9}$ & $\mathbf{2 0 0 2}$ & \\
\hline Kota/Urban & 0.35 & 0.07 & 0.06 & -31.43 \\
Desa/Rural & 0.07 & 0.07 & 0.05 & -9.52 \\
\hline
\end{tabular}

